\title{
Preparation of Magnesium-zinc Alloy by Mechanical Alloying
}

Michaela Fousova, Jaroslav Capek, Dalibor Vojtech

Faculty of Chemical Technology, Department of Metals and Corrosion Engineering, Institute of Chemical Technology, Technická 5, 16628 Prague 6, Czech Republic.E-mail: fousovam@vscht.cz, capekj@vscht.cz, dalibor.vojtech@vscht.cz

Mechanical alloying is one of the ways how to prepare nanostructured and amorphous metallic materials. In this paper we used this method to prepare $\mathrm{Mg}-\mathrm{Zn}$ alloy containing $50 \mathrm{wt} \%$ of zinc. Powders produced by milling in a planetary ball mill were consequently compacted by the SPS method, a very fast method which prevents grain coarsening. The prepared samples were subjected to a closer examination - microstructure, phase composition, hardness and short-term thermal stability were studied. We found out that the prepared powder consisted of Mg and $\mathrm{Mg}_{7} \mathrm{Zn}_{3}$ phases, which were very fine and homogeneously distributed. After the SPS compacting, the metastable $\mathrm{Mg}_{7} \mathrm{Zn}_{3}$ phase decomposed and new phases $\left(\mathrm{Mg}, \operatorname{MgZn}, \operatorname{MgZn} 2, \mathrm{Mg}_{2} \mathrm{Zn}_{11}\right)$ formed. The compacted sample possessed relatively inhomogeneous microstructure and hardness about $260 \mathrm{HV} 5$. Investigation of the short-term thermal stability was accomplished by annealing at temperatures up to $300{ }^{\circ} \mathrm{C}$. We observed changes in hardness - it regularly decreased up to $200^{\circ} \mathrm{C}$ and then it slightly increased.

Keywords: Mg-Zn alloy, mechanical alloying, SPS

\section{Acknowledgement}

The authors would like to thank to the Czech science foundation (project no. P108/12/G043).

\section{References}

[1] SCHROERS, J., KUMAR, G., HODGES, T. M., CHAN, S., et al. (2009). Bulk metallic glasses for biomedical applications. In: Jom, Vol. 61, No. 9, pp. 21-29.

[2] ZBERG, B., UGGOWITZER, P. J., LOFFLER, J. F. (2009). MgZnCa glasses without clinically observable hydrogen evolution for biodegradable implants. In: Nature Materials, Vol. 8, No. 11, pp. 887-891.

[3] MA, E., XU, J. (2009). BIODEGRADABLE ALLOYS The glass window of opportunities. In: Nature Materials, Vol. 8, No. 11, pp. 855-857.

[4] MICHAlCOVA, A., VOJTECH, D., CIZEK, J., PROCHAZKA, I., et al. (2011). Microstructure characterization of rapidly solidified Al-Fe-Cr-Ce alloy by positron annihilation spectroscopy. In: Journal of Alloys and Compounds, Vol. 509, No. 7, pp. 3211-3218.

[5] CALKA, A., RADLINSKI, A. P. (1989). Amorphization of Mg-Zn alloys by mechanical alloying. In: Materials Science and Engineering a-Structural Materials Properties Microstructure and Processing, Vol. 118, pp. 131135.

[6] SURYANARAYANA, C.; IVANOV, E.; BOLDYREV, V. V. (2001). The science and technology of mechanical alloying. In: Materials Science and Engineering a-Structural Materials Properties Microstructure and Processing, Vol. 304, pp. 151-158.

[7] SURYANARAYANA, C. (2001). Mechanical alloying and milling. In: Progress in Materials Science, Vol. 46, No. 1-2, pp. 1-184.

[8] GOVIND, NAIR, K. S., MITTAL, M. C., LAL, K., et al. (2001). Development of rapidly solidified (RS) magnesium-aluminium-zinc alloy. In: Materials Science and Engineering a-Structural Materials Properties Microstructure and Processing, Vol. 304, pp. 520-523.

[9] OMORI, M. (2000). Sintering, consolidation, reaction and crystal growth by the spark plasma system (SPS). Materials Science and Engineering a-Structural Materials Properties Microstructure and Processing, Vol. 287, No.2, pp. 183-188.

[10]MUNIR, Z. A., ANSELMI-TAMBURINI, U., OHYANAGI, M. (2006). The effect of electric field and pressure on the synthesis and consolidation of materials: A review of the spark plasma sintering method. In: Journal of Materials Science, Vol. 41, No. 3, pp. 763-777. 